\title{
Amyloidosis of the breast: predominantly AL type and over half have concurrent breast hematologic disorders
}

\author{
Samar M Said, Carol Reynolds, Rafael E Jimenez, Beiyun Chen, Julie A Vrana, \\ Jason D Theis, Ahmet Dogan and Sejal S Shah
}

Division of Anatomic Pathology, Mayo Clinic, Rochester, MN, USA

\begin{abstract}
Amyloidosis is a disorder characterized by extracellular deposition of proteins in an abnormal fibrillar configuration. Amyloidosis can be localized or systemic and may affect any organ. Breast involvement by amyloidosis has rarely been reported. In this study, we described the characteristics of 40 cases of breast amyloidosis that were reviewed at the Division of Anatomic Pathology at Mayo Clinic from 1995 to 2011. The cohort included 39 women and 1 man with a mean age of 60 years. The type of amyloidosis, determined by immunohistochemistry or mass spectrometry-based proteomics in $\mathbf{2 6}$ patients, was immunoglobulin-associated in all cases (AL-kappa type in $15(58 \%)$ cases, AL-lambda in $10(38 \%)$ and mixed heavy and light chains (AH/AL) in $1(4 \%)$ case). Mass spectrometry-based proteomics was able to determine the type of amyloidosis in $95 \%$ of cases tested compared with $69 \%$ of cases by immunohistochemistry. In addition to amyloidosis, the breast biopsy showed a hematologic disorder in $\mathbf{5 5 \%}$ of cases, most commonly MALT lymphoma. One patient had concurrent intraductal carcinoma, but none had invasive carcinoma. Of the 15 patients seen in our institution, 53\% had localized amyloidosis and $47 \%$ had extramammary amyloid involvement, which was diagnosed before breast amyloidosis in most patients. M-spike was detected in the blood in $62 \%$. After a median follow-up of 33.5 months in 12 patients, 5 died, mostly of complications of lymphoma or leukemia. In conclusion, our findings indicate that breast amyloidosis is of the AL type in the vast majority of patients (usually kappa). It is associated with systemic amyloidosis in close to half of patients and with hematologic malignancy in the breast in over half of patients. Therefore, further work up to rule out hematologic malignancy and/or systemic amyloidosis is recommended. Mass spectrometry-based proteomics is superior to immunohistochemistry for typing of breast amyloidosis. Modern Pathology (2013) 26, 232-238; doi:10.1038/modpathol.2012.167; published online 28 September 2012
\end{abstract}

Keywords: breast amyloid; lymphoma; mass spectrometry

Amyloidosis is an uncommon disorder characterized by extracellular deposition of proteins in an abnormal fibrillar, beta-pleated sheet format. In tissue, the amyloid deposits are identified by Congo red histochemical stain, which produces applegreen birefringence when viewed under polarized light. More than 20 precursor proteins of amyloid have been identified so far. The most common types of amyloidosis are immunoglobulin (Ig) lightchain amyloidosis (AL) secondary to plasma cell dyscrasia, and reactive, so-called secondary (AA) amyloidosis associated with chronic inflammatory

Correspondence: Dr SM Said, MD, Division of Anatomic Pathology, Mayo Clinic, Hilton 11, 200 First Street, SW, Rochester, MN, 55905, USA.

E-mail: said.samar@mayo.edu

Received 11 June 2012; revised 31 July 2012; accepted 1 August 2012; published online 28 September 2012 diseases. Other precursor proteins associated with amyloidosis include transthyretin (TTR), fibrinogen A $\alpha$-chain, apolipoprotein AI, apolipoprotein AII, lysozyme, gelsolin, cystatin $\mathrm{C}, \beta 2$ microglobulin and leukocyte chemotactic factor 2 (LECT2). ${ }^{1,2} \mathrm{AL}$ amyloidosis can be localized or systemic, and when systemic, it commonly involves the heart, kidney, gastrointestinal tract and tongue. ${ }^{1}$

Breast amyloidosis is rare. It can be part of a systemic disease or it may be localized to the breast. $^{3-10}$ It is typically unilateral, although bilateral involvement has been described. ${ }^{11}$ Some of the reported cases were associated with malignancy, including invasive ductal or lobular carcinoma, ${ }^{3,4,12}$ or non-Hodgkins lymphoma. ${ }^{4}$ The typical clinical presentation is painless, solitary breast mass, which may or may not be associated with calcifications.

The largest case series of breast amyloidosis reported so far was from the Boston Medical Center 
by Charlot et $a .^{3}$ who described seven patients with localized amyloidosis who presented with abnormal screening mammography and calcifications. Immunohistochemistery, performed in three patients, was negative for Ig light chains, TTR and serum amyloid-associated (SAA) protein. One case was associated with infiltrating ductal carcinoma. None of these patients had clinical or laboratory evidence of other organ involvement. We report our experience with 40 cases of breast amyloidosis that were reviewed at the Division of Anatomic Pathology at Mayo Clinic, Rochester. The large cohort of patients in this study has the advantage of allowing us to define the characteristics of breast amyloidosis, including the precursor protein, presentation, associated malignancy and outcome.

\section{Materials and methods}

Approval from the Institutional Review Board was obtained for this study. Demographic information, clinical and radiological findings, treatment and outcome for 15 patients that were seen in our institution were obtained from the patients' electronic medical records. Clinical data on the remaining patients who were followed at outside institutions were not available.

We reviewed the pathology archives at Mayo Clinic, Rochester, from January 1995 to September 2011, and identified 44 patients with a pathological diagnosis of breast amyloidosis. Four cases were excluded from this study because the results of Congo red staining were not available. In the remaining 40 cases, which comprise the study cohort, the amyloid deposits stained positive with Congo red and showed an apple-green birefringence when viewed under polarized light. In four patients, the breast biopsies were performed at our medical center. In the remaining cases, the biopsies were performed at outside institutions and the materials were sent to us for a second opinion or for amyloid typing. Cases were stained with hematoxylin and eosin and Congo red.

Typing of amyloidosis was performed by immunohistochemistry and/or liquid chromatography tandem mass spectrometry. Amyloid typing by immunohistochemistry was performed by immunoperoxidase staining on paraffin sections of the breast biopsy using antibodies directed against the following antigens: TTR, $\beta 2$ microglobulin, SAA, serum amyloid $\mathrm{P}$ component and kappa and lambda Ig light chains. ${ }^{13}$

Amyloid typing by mass spectrometry-based proteomics was performed on peptides extracted from congo red-positive/microdissected areas of paraffinembedded breast specimen. The methods for mass spectrometry-based proteomics in our center have previously been published. ${ }^{14-16}$ Briefly, for each case, $10 \mu \mathrm{m}$-thick sections of formalin-fixed paraffin- embedded tissues were stained with Congo red. The Congo red deposits were identified under fluorescence light and laser microdissected. The dissected fragments were digested into tryptic peptides and analyzed by liquid chromatography electrospray tandem mass spectrometry. Mass spectrometrybased proteomics raw data files were queried using three different algorithms (Sequest, Mascot and X! Tandem), and the results were combined and assigned peptide and protein probability scores in Scaffold (Proteome Software, Portland, OR, USA). For each case, a list of proteins based on peptides identified by mass spectrometry-based proteomics was generated. Peptide identifications were accepted if they could be established at $>90.0 \%$ probability. Protein identifications below the 90\% confidence level and those with single peptide identification were not considered in our analysis. The spectra value indicates the total number of mass spectrum collected on the mass spectrometer and matched to the protein using the proteomic software. A higher number of mass spectra is indicative of greater abundance and will typically yield greater aminoacid sequence coverage. A higher mass spectra value also indicates a higher confidence in protein identification. Our clinical amyloid testing requires a minimum number of four spectra in all samples before the protein identification will be deemed clinically valid.

Chi-square testing was used to detect differences between groups. In all cases, two-tailed testing was performed and all $P$-values refer to these results. The threshold of significance was defined as a $P$-value $<0.05$.

\section{Results}

The study cohort consisted of 39 women and 1 man with a mean age at biopsy of 60 years (range 38-85 years). The indications for breast biopsy were breast mass (detected by the patient or by imaging studies) in $13(33 \%)$ cases, calcifications in $6(15 \%)$ and unknown in $21(53 \%)$ (Table 1). In the majority of cases, breast amyloidosis was not suspected clinically and breast biopsies were done to exclude malignancy. Amyloid deposition was identified in the right breast in 21 (53\%) patients, in the left breast in $16(40 \%)$ and was bilateral in $2(5 \%)$. The location was not indicated in $1(3 \%)$ patient. The amyloid deposits appeared as eosinophilic amorphous material within the fat, fibrous tissue and blood vessels (Figure 1). All cases showed characteristic staining with Congo red (Figure 2). Multinucleated giant cells were common. The type of amyloidosis, determined by immunohistochemistry or mass spectrometrybased proteomics, was AL (light chain) in 25 $(63 \%)$ cases, of which $15(60 \%)$ were of AL-kappa and $10(40 \%)$ were of AL-lambda, and mixed heavy and light chains (AH/AL) in $1(3 \%)$ case, which was of IgA/lambda type (Table 1). None of the 
Table 1 Characteristic features of 40 cases of breast amyloidosis

\begin{tabular}{|c|c|c|}
\hline Parameters & $\begin{array}{c}\text { No. of } \\
\text { patients } \\
(\%)\end{array}$ & P-value \\
\hline Mean age in years (range) & $60(38-85)$ & \\
\hline $\begin{array}{l}\text { Gender } \\
\text { Female } \\
\text { Male }\end{array}$ & $\begin{array}{c}39(98 \%) \\
1(3 \%)\end{array}$ & 0.0001 \\
\hline $\begin{array}{l}\text { Side } \\
\text { Right } \\
\text { Left } \\
\text { Bilateral } \\
\text { Unknown }\end{array}$ & $\begin{array}{l}21(53 \%) \\
16(40 \%) \\
2(5 \%) \\
1(3 \%)\end{array}$ & 0.5 (right vs left) \\
\hline $\begin{array}{l}\text { Additional breast findings } \\
\text { MALT lymphoma } \\
\text { Plasma cell proliferative } \\
\text { disorder/plasmacytoma } \\
\text { Chronic lymphoid leukemia }\end{array}$ & $\begin{array}{r}14(35 \%) \\
7(18 \%) \\
1(3 \%)\end{array}$ & $\begin{array}{l}0.2 \text { (MALT vs } \\
\text { plasma } \\
\text { cell } \\
\text { proliferative } \\
\text { disorder/ } \\
\text { plasmacytoma) }\end{array}$ \\
\hline $\begin{array}{l}\text { Type of amyloid } \\
\text { AL } \\
\text { Kappa } \\
\text { Lambda } \\
\text { AH/AL } \\
\text { Unknown }\end{array}$ & $\begin{array}{c}25(63 \%) \\
15(60 \%) \\
10(40 \%) \\
1(3 \%) \\
14(35 \%)\end{array}$ & $\begin{array}{c}0.4 \text { (kappa vs } \\
\text { lambda) }\end{array}$ \\
\hline $\begin{array}{l}\text { Indications for biopsy } \\
\text { Mass } \\
\text { Calcifications } \\
\text { Unknown }\end{array}$ & $\begin{array}{r}13(33 \%) \\
6(15 \%) \\
21(53 \%)\end{array}$ & $\begin{array}{l}0.1 \text { (mass vs } \\
\text { calcification) }\end{array}$ \\
\hline
\end{tabular}

${ }^{\mathrm{a}}$ With plasmacytic differentiation in seven patients.

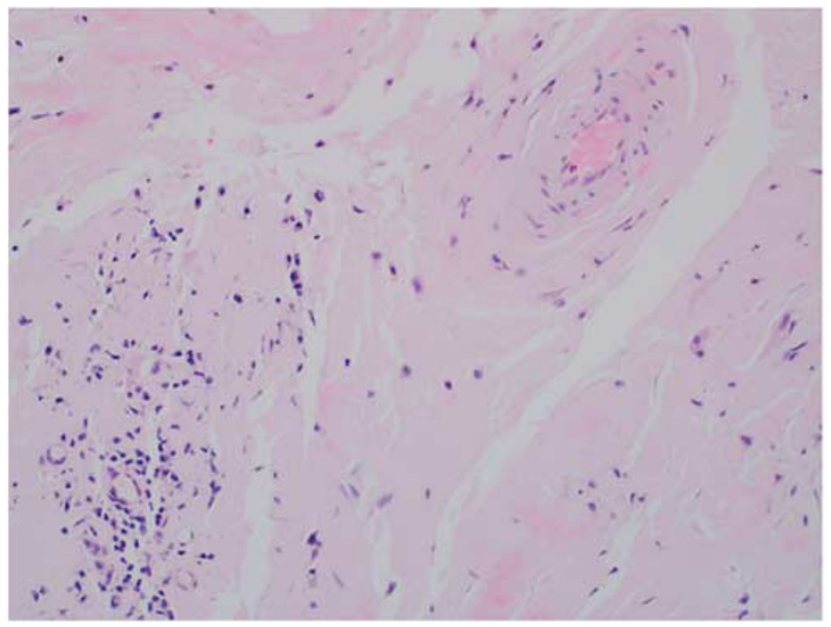

Figure 1 Amyloidosis of the breast. There is stromal and vascular amorphous eosinophilic material, consistent with amyloid (hematoxylin and eosin, $\times 400$ ).

cases showed secondary (AA) amyloidosis or other types of amyloidosis. For the remaining 14 (35\%) cases, typing was not performed (9 cases) or was inconclusive (5 cases). Mass spectrometry-based proteomics established the type of amyloid in 18 out of $19(95 \%)$ cases tested. In the remaining
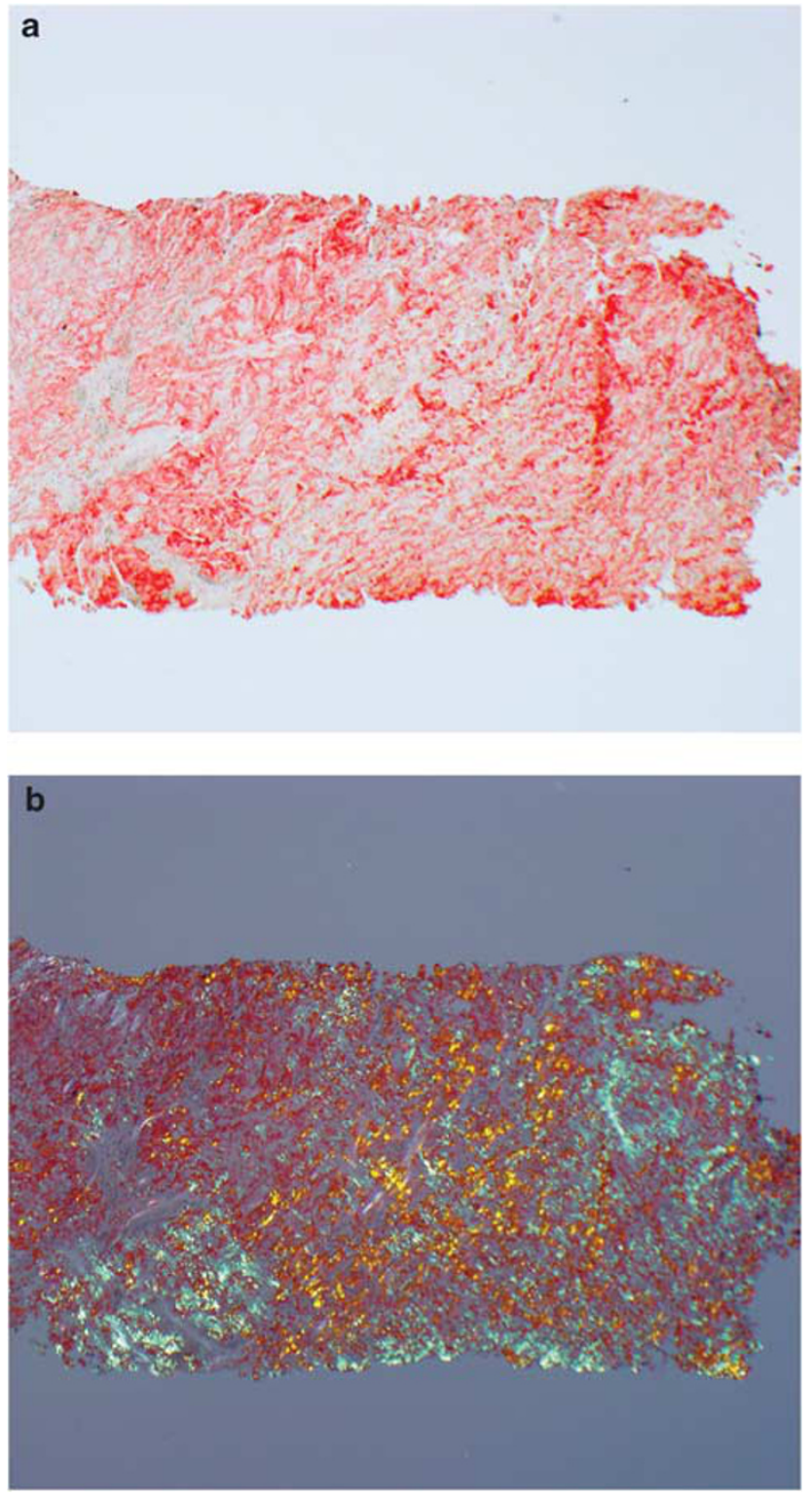

Figure 2 Amyloidosis of the breast. Extensive stromal amyloid deposits stain positively for Congo red (a) and show apple-green birefringence under polarized light $(\mathbf{b})(\times 100)$.

patient, amyloid deposits were of Ig type where Ig gamma heavy chain, Ig lambda light chains and Ig kappa light chains were detected by mass spectrometry-based proteomics but none of them predominated. In contrast, immunohistochemistry established the type of amyloidosis in only 9 out of $13(69 \%)$ cases tested and was inconclusive in the remaining $4(31 \%)$ cases. One case was typed by both immunohistochemistry and mass spectrometry-based proteomics and was of the ALlambda type.

In addition to amyloid deposits, the breast biopsy showed a concomitant hematologic disorder in 22 $(55 \%)$ cases (Figure 3): extranodal marginal zone B-cell lymphoma (MALT lymphoma) in 14 (35\%) cases, plasma cell proliferative disorder in $6(15 \%)$ 


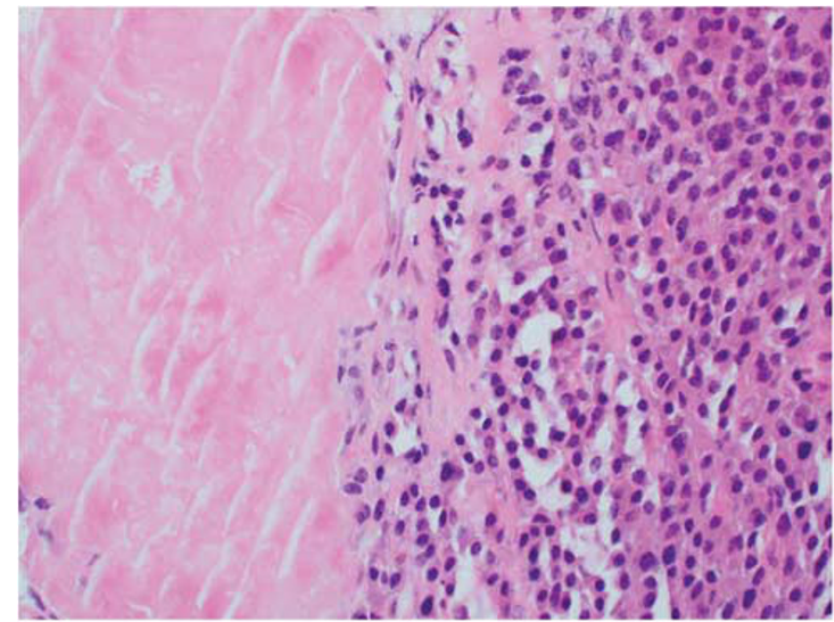

Figure 3 Breast plasmacytoma with amyloidosis. There are sheets of atypical plasma cells adjacent to amyloid deposits (hematoxylin and eosin, $\times 400$ ).

cases, plasmacytoma in $1(3 \%)$ case and chronic lymphoid leukemia in $1(3 \%)$ case. In one additional patient, two previous unilateral biopsies performed 5 years prior to the biopsy that showed amyloidosisexhibited lymphoma; the first one showed lowgrade lymphoma and the subsequent one showed diffuse large B-cell lymphoma. One patient with breast amyloidosis and MALT lymphoma also had ductal carcinoma in situ, whereas none of the 40 patients had invasive carcinoma.

Of the 15 patients seen at our institution who were all Caucasian, 8 (53\%) had localized amyloidosis (confined to the breast) and $7(47 \%)$ had amyloid deposition in one or more additional organ sites (skin in three patients, lymph nodes in two, heart in two, soft tissue in one, tongue in one, lung/pleura in one, submandibular gland in one, kidney in one and nerves in one) (Table 2). The extramammary amyloidosis was diagnosed 6-144 months (mean 93 months) prior to the breast amyloidosis in 6 patients and concomitantly with the breast amyloidosis in the remaining patient. M-spike was detected on serum protein electrophoresis/serum immunofixation electrophoresis in 8 out of the $13(62 \%)$ patients tested and on urine protein electrophoresis/urine immunofixation electrophoresis in 4 out of the $15(27 \%)$ patients. Serum-free light-chain assay was performed in $9(60 \%)$ patients. Serum-free kappa to lambda ratio was abnormal $(<0.26$ or $>1.65)$ in $4(44 \%)$ and normal in $5(56 \%)$ patients. Bone marrow biopsy, performed in 14 patients (93\%), showed amyloid in 1 patient, which was of AL-lambda type similar to the breast, plasma cell dyscrasia in 3 patients, lymphoma in 2 patients and was unremarkable in the remaining 8 patients (Table 2). Abdominal fat pad biopsy, performed in 7 patients $(47 \%)$, was positive for amyloid in only 1 patient (14\%). Follow-up was available in 12 of these $15(80 \%)$ patients. The median duration of follow-up was 33.5 months (range 4-141). On follow-up, 5 (42\%) patients died: 2 of complications of lymphoma (pleural effusions), 1 of pneumonia in the setting of leukemia, 1 of congestive heart failure and 1 of unknown cause at the age of 90 years. The therapy for these patients is summarized in Table 2. Patients with systemic amyloidosis and/or associated hematologic disorders were treated with chemotherapy with or without radiation, whereas patients with localized breast amyloidosis without hematologic disorder were not treated. None of the patients with localized breast amyloidosis at diagnosis developed extramammary amyloidosis on follow-up.

\section{Discussion}

This study reports our experience with a series of 40 patients with breast amyloidosis which is, to our knowledge, the largest clinicopathological series of breast amyloidosis. Our findings indicate that breast amyloidosis is typically of the AL type, as $96 \%$ of cases in our series in which the amyloid type was determined were of AL type. Noticeably, none of the cases were of the AA type, which is the second most common type of systemic amyloidosis. Rocken et al. ${ }^{4}$ described three cases of breast AL amyloidosis in 2002 and reviewed the characteristics of 42 previously reported cases. Amyloid type was available in 18 of these 42 cases and was AL in 15 cases, AA in 2 cases and $\mathrm{AH}$ in 1 case. Interestingly, AL amyloidosis was kappa type in $60 \%$ of our cases and in $67 \%$ of the previously reported cases reviewed by Rocken et al. ${ }^{4}$ This is in contrast to AL amyloidosis in general, in which twothirds of cases are of lambda type. ${ }^{17}$

Forty-seven percent of patients with breast amyloidosis seen at our medical center had systemic AL amyloidosis. Therefore, work up to rule out systemic amyloidosis, including serum protein electrophoresis/serum immunofixation electrophoresis, urine protein electrophoresis/urine immunofixation electrophoresis, free light-chain assay and bone marrow biopsy, is recommended. Extramammary amyloidosis was diagnosed prior to breast amyloidosis in the majority of our patients, and none of those with localized breast amyloidosis at the time of diagnosis subsequently developed systemic amyloidosis. This suggests that breast involvement by amyloidosis is generally a late development.

Localized breast amyloidosis without associated hematologic disorder appears to be a benign disease. This is supported by the fact that none of the two patients in this category in our study with an available follow-up of 32 and 141 months and none of the seven patients reported by Charlot et al. ${ }^{3}$ with a median follow-up of 6 years died of amyloid complications or later developed systemic amyloidosis or plasma cell dyscrasia. Therefore, long-term hematologic follow-up might not be necessary for these patients but more studies are needed. The 
Table 2 Clinical characteristics of 15 Mayo Clinic patients with breast amyloidosis

\begin{tabular}{|c|c|c|c|c|c|c|c|c|c|c|}
\hline $\begin{array}{l}\text { Patient } \\
\text { number }\end{array}$ & Age & $\begin{array}{l}\text { Gender/ } T \\
\text { race }\end{array}$ & Type of amyloid & \multicolumn{2}{|c|}{$\begin{array}{l}\text { Concomitant breast } \\
\text { hematologic } \\
\text { malignancy }\end{array}$} & \multicolumn{2}{|c|}{$\begin{array}{l}\text { Extramammary } \\
\text { amyloidosis }\end{array}$} & \multicolumn{2}{|c|}{$\begin{array}{l}\text { Extramammary } \\
\text { hematologic malignancy }\end{array}$} & $\begin{array}{l}\text { Bone marrow biopsy } \\
\text { findings }\end{array}$ \\
\hline 1 & 78 & F/Cau N & ND & \multicolumn{2}{|l|}{ None } & \multicolumn{2}{|c|}{ None } & \multicolumn{2}{|l|}{ None } & ND \\
\hline 2 & 52 & $\mathrm{~F} / \mathrm{Cau} \quad \mathrm{A}$ & AL- $\lambda$ (by MS \& IHC) & \multicolumn{2}{|c|}{$\begin{array}{l}\text { MALT lymphoma } \\
\text { ( } \lambda \text {-restricted) }\end{array}$} & \multicolumn{2}{|c|}{$\begin{array}{l}\text { Heart, lymph nodes } \\
\text { (axillary) }\end{array}$} & \multicolumn{2}{|l|}{ None } & $\begin{array}{l}\text { Amyloid } \\
\text { (AL- } \lambda \text { by MS) }\end{array}$ \\
\hline 3 & 64 & F/Cau A & AL- $\kappa$ (by MS) & \multicolumn{2}{|c|}{$\begin{array}{l}\text { Plasmacytoma } \\
\text { ( } \kappa \text {-restricted) }\end{array}$} & \multicolumn{2}{|c|}{ None } & \multicolumn{2}{|l|}{$\begin{array}{l}\text { Plasmacytoma (ribs, } \\
\text { femur, chest wall) }\end{array}$} & $\begin{array}{l}5 \% \kappa \text {-restricted } \\
\text { plasma cells }\end{array}$ \\
\hline 4 & 58 & $\mathrm{~F} / \mathrm{Cau} \quad \mathrm{A}$ & AL- $\lambda$ (by MS) & \multicolumn{2}{|c|}{$\begin{array}{l}\text { MALT lymphoma } \\
\text { ( } \lambda \text {-restricted) }\end{array}$} & \multicolumn{2}{|c|}{$\begin{array}{l}\text { Lung, kidney, soft } \\
\text { tissue (paraspinal) }\end{array}$} & \multicolumn{2}{|c|}{$\begin{array}{l}\text { MALT lymphoma } \\
\text { (paraspinal soft tissue) }\end{array}$} & Neg \\
\hline 5 & 56 & F/Cau N & ND & \multicolumn{2}{|c|}{$\begin{array}{l}\text { MALT lymphoma } \\
(\lambda \text {-restricted) }\end{array}$} & \multicolumn{2}{|c|}{ None } & \multicolumn{2}{|c|}{ None } & Neg \\
\hline 6 & 55 & F/Cau N & ND & $\begin{array}{l}\text { MALT lyı } \\
\text { ( } \kappa \text {-restrict }\end{array}$ & $\begin{array}{l}\text { phoma } \\
\text { d) }\end{array}$ & Skin & & $\begin{array}{l}\text { Small lymphocytic } \\
\text { lymphoma (right leg }\end{array}$ & & Neg \\
\hline 7 & 62 & F/Cau N & ND & None & & $\begin{array}{l}\text { Lym } \\
\text { (retr }\end{array}$ & $\begin{array}{l}\text { ph nodes } \\
\text { pperitoneal) }\end{array}$ & $\begin{array}{l}\text { Lymphoplasmacytic } \\
\text { lymphoma (retroper } \\
\text { lymph node) }\end{array}$ & toneal & $\begin{array}{l}\text { Lymphoplasmacytic } \\
\text { lymphoma }\end{array}$ \\
\hline 8 & 52 & $\begin{array}{ll}\text { F/Cau } & \text { M } \\
& \text { (I }\end{array}$ & $\begin{array}{l}\text { Mixed AH/AL } \\
\text { IgA- } \lambda \text { ) (by MS) }\end{array}$ & $\begin{array}{l}\text { Scattered } \\
\text { expressin } \\
\lambda\end{array}$ & $\begin{array}{l}\text { lasma cells } \\
\text { monotypic }\end{array}$ & None & & None & & Neg \\
\hline 9 & 66 & F/Cau A & AL- $\kappa$ (by MS) & None $^{b}$ & & None & & None & & $\begin{array}{l}\text { Low-grade B-cell } \\
\text { lymphoma }\end{array}$ \\
\hline 10 & 72 & $\begin{array}{ll}\text { F/Cau } & \mathrm{N} \\
& \mathrm{su} \\
& \mathrm{gl}\end{array}$ & $\begin{array}{l}\text { ND (AL- } \kappa \text { by MS on } \\
\text { submandibular } \\
\text { sland) }\end{array}$ & None & & $\begin{array}{l}\text { Tong } \\
\text { subn } \\
\text { glan }\end{array}$ & $\begin{array}{l}\text { ue, } \\
\text { handibular } \\
\text { d, heart, nerves }\end{array}$ & None & & $\begin{array}{l}15 \% \kappa \text {-restricted } \\
\text { plasma cells }\end{array}$ \\
\hline 11 & 53 & F/Cau A & $A L-\kappa$ & $\begin{array}{l}\text { MALT lyı } \\
\text { ( } \kappa \text {-restrict }\end{array}$ & $\begin{array}{l}\text { phoma } \\
\text { d) }\end{array}$ & Skin & & $\begin{array}{l}\text { MALT lymphoma } \\
\text { (nasopharynx, orbit) }\end{array}$ & & Neg \\
\hline 12 & 48 & $\begin{array}{ll}\text { F/Cau } & \text { In } \\
& \text { IH }\end{array}$ & $\begin{array}{l}\text { nconclusive (by } \\
\text { HC) }\end{array}$ & $\begin{array}{l}\text { MALT lyı } \\
(\lambda \text {-restrict }\end{array}$ & $\begin{array}{l}\text { phoma } \\
\text { d) }\end{array}$ & None & & None & & Neg \\
\hline 13 & 54 & F/Cau N & ND & None & & None & & None & & $\begin{array}{l}10 \% \kappa \text {-restricted } \\
\text { plasma cells }\end{array}$ \\
\hline 14 & 63 & $\mathrm{~F} / \mathrm{Cau} \quad \mathrm{Nl}$ & ND & None & & None & & None & & Neg \\
\hline 15 & 38 & $\begin{array}{ll}\text { F/Cau } & \text { In } \\
& \text { IH }\end{array}$ & $\begin{array}{l}\text { nconclusive (by } \\
\text { HC) }\end{array}$ & $\begin{array}{l}\text { MALT lyı } \\
\text { ( } \kappa \text {-restrict }\end{array}$ & $\begin{array}{l}\text { phoma }{ }^{a} \\
\text { d) }\end{array}$ & Skin & & None & & Neg \\
\hline $\begin{array}{l}\text { Patient } \\
\text { number }\end{array}$ & & $\begin{array}{l}\text { 1-spike on } \\
\text { SPEP/SIFE }\end{array}$ & 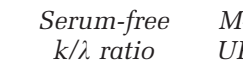 & $\begin{array}{l}\text { M-spike on } \\
\text { UPEP/UIFE }\end{array}$ & $\begin{array}{l}\text { Duration of } \\
\text { in montl }\end{array}$ & $\begin{array}{l}\mathrm{f} F / \mathrm{U} \\
\mathrm{hs}\end{array}$ & Treatment & & Follo & -up \\
\hline 1 & & ND & ND & Neg & 141 & & None & & Died & f unknown cause \\
\hline 2 & & $\lambda$ & ND & $\lambda$ & 12 & & Chemotherapy & (C, P then R-CHOP) & $\begin{array}{l}\text { Died } \\
\text { lymp }\end{array}$ & $\begin{array}{l}\text { f complications of } \\
\text { oma }\end{array}$ \\
\hline 3 & & $\begin{array}{l}\mathrm{g} F(1.1 \mathrm{~g} / \\
\mathrm{dl})\end{array}$ & ND & $\operatorname{IgG} \kappa$ & 9 & & $\begin{array}{l}\text { Chemotherapy } \\
\text { VBAP) and rac }\end{array}$ & $\begin{array}{l}\text { (M, P, thalidomide, } \\
\text { iation }\end{array}$ & $\begin{array}{l}\text { Died } \\
\text { settin }\end{array}$ & $\begin{array}{l}\text { f pneumonia in the } \\
\text { of leukemia }\end{array}$ \\
\hline 4 & $\operatorname{IgC}$ & $\lambda \lambda(0.6 \mathrm{~g} / \mathrm{dl})$ & $\begin{array}{c}\text { Abnormal } \\
(0.22)\end{array}$ & Neg & 10 & & Chemotherapy & (R-CVP) & Alive & \\
\hline 5 & & $\operatorname{IgG} \lambda$ & ND & Neg & No $F / U$ & & Lumpectomy a & nd radiation & Alive & \\
\hline 6 & & ND & ND & Neg & 77 & & None & & $\begin{array}{l}\text { Died } \\
\text { failur }\end{array}$ & f congestive heart \\
\hline 7 & & $\lambda(0.5 \mathrm{~g} / \mathrm{dl})$ & ND & $\operatorname{IgG} \lambda$ & 31 & & $\begin{array}{l}\text { Chemotherapy } \\
\text { novantrone, P, }\end{array}$ & $\begin{array}{l}\text { (fludarabine, } \\
\text { R) and radiation }\end{array}$ & $\begin{array}{l}\text { Died } \\
\text { lymp }\end{array}$ & $\begin{array}{l}\text { f complications of } \\
\text { oma }\end{array}$ \\
\hline 8 & & Neg & $\begin{array}{l}\text { Normal } \\
(0.66)\end{array}$ & Neg & No $F / U$ & & None & & Álive & \\
\hline 9 & & $\operatorname{IgM} \kappa$ & $\begin{array}{l}\text { Normal } \\
(0.85)\end{array}$ & Neg & 4 & & Chemotherapy & (R-CHOP) & Alive & \\
\hline 10 & & A $\kappa$ (small) & $\begin{array}{l}\text { Abnormal } \\
(7.18)\end{array}$ & $\operatorname{IgA} \kappa$ & 83 & & Chemotherapy & (M, revlimid, $\mathrm{P}$ ) & Alive & \\
\hline 11 & & Neg & $\begin{array}{c}\text { Normal } \\
(1.52)\end{array}$ & Neg & 111 & & $\begin{array}{l}\text { Chemotherapy } \\
\text { Enbrel, R) }\end{array}$ & (M, P, thalidomide, & Alive & \\
\hline 12 & & Neg & Normal (1.0) & Neg & 6 & & None & & Alive & \\
\hline 13 & & $\begin{array}{l}\mathrm{g} \kappa(0.8 \mathrm{~g} / \\
\mathrm{dl})\end{array}$ & $\begin{array}{c}\text { Abnormal } \\
(4.82)\end{array}$ & Neg & No $F / U$ & & None & & Alive & \\
\hline 14 & & Neg & Normal (0.8) & Neg & 32 & & None & & Alive & \\
\hline 15 & & Neg & $\begin{array}{c}\text { Abnormal } \\
(4.39)\end{array}$ & Neg & 35 & & None & & Alive & \\
\hline
\end{tabular}

Abbreviations: C, cyclophosphamide; Cau, Caucasian; CHOP, cyclophosphamide, hydroxydaunorubicin, vincristine and steroid; F, female; F/U, follow-up; IHC, immunohistochemistry; M, melphalan; MS, mass spectrometry-based proteomics; ND, not done; P, steroid; R, rituximab; SPEP/ SIFE, serum protein electrophoresis/serum immunofixation electropheresis; UPEP/UIFE, urine protein electrophoresis/urine immunofixation electrophoresis; V, vincristine; VBAP, vincristine, carmustine, doxorubicin and P.

${ }^{\text {a }}$ With plasmacytic differentiation.

bow-grade lymphoma and diffuse large B-cell lymphoma in prior biopsies. 
prognosis in those with associated hematologic disorder is guarded and largely dependent on the hematologic disease. In our study, 3 of the 10 patients with associated hematologic disorder died of lymphoma/leukemia complications.

Two of the three cases of breast amyloidosis reported by Rocken et $a l^{4}{ }^{4}$ and one of the seven cases reported by Charlot et $a l^{3}$ were associated with invasive carcinoma (ductal in two patients and lobular in one patient). In contrast, only 1 of the 40 patients in our study had ductal carcinoma in situ and none had invasive cancer. Importantly, 55\% of patients in our series had a hematologic disorder in the breast, most commonly MALT lymphoma. This association has been reported previously in only a handful of cases. ${ }^{18-20}$

Breast amyloidosis lacks specific clinical or radiographic features. In the majority of cases, amyloidosis is not suspected clinically; instead, breast biopsies are usually done to rule out malignancy. Therefore, breast biopsy is essential to establish the diagnosis of breast amyloidosis and avoid unnecessary surgical interventions.

Establishing the type of amyloidosis is essential for prognosis and treatment. Traditionally, amyloid typing is performed by immunohistochemistry or immunofluorescence. More recently, the technique of laser microdissection mass spectrometry-based proteomics was introduced as a powerful tool for the diagnosis and typing of amyloidosis with high sensitivity and specificity. ${ }^{14-16}$ It is particularly helpful in diagnosing some of the rare forms of amyloidosis, such as fibrinogen $\mathrm{A} \alpha$-chain, apolipoprotein AI, apolipoprotein AII, ALECT2, AH and AH/AL, which may not be diagnosed by immunohistochemistry. One of the most practical aspects of the technique of mass spectrometry-based proteomics for amyloid typing is that it is done on formalin-fixed paraffin-embedded tissue instead of requiring fresh, frozen or other specially stored tissue samples. Since 2007, we have been using mass spectrometry-based proteomics in our center to determine the type of amyloid on biopsies from bone marrow, fat pad, heart, kidney and other organs including breast. Some of the advantages of mass spectrometry-based proteomics over immunohistochemistry are that it is a single test that can identify the precursor protein of amyloid instead of testing the sample with multiple different antibodies, and it requires only a small amount of tissue, so that it can be done in small needle biopsies. In our study, mass spectrometry-based proteomics was able to determine the type of amyloidosis in $95 \%$ of cases tested compared with $69 \%$ of cases by immunohistochemistry. This study suggests that mass spectrometry-based proteomics is superior to immunohistochemistry for breast amyloid typing.

The pathogenesis of localized breast amyloidosis in the absence of concurrent lymphoma or plasma cell dyscrasia is unknown. The fact that it is usually of the AL type, based on our data, would suggest that localized breast amyloidosis most likely originates from local plasma cells secreting immunoglobulins. Plasma cell proliferation by itself is probably not sufficient to trigger amyloid deposition, and undetermined factors are needed for amyloid deposition. ${ }^{3,21}$

Primary malignant lymphomas constitute approximately $0.15 \%$ of malignant neoplasms of the breast. Diffuse large B-cell lymphoma is the most common type, followed by small lymphocytic and follicular types. MALT lymphoma is uncommon in the breast. Lin et $a l^{22}$ have recently reported a series of 42 cases of breast lymphoma. Of the 23 primary lymphoma cases in their series, 20 were diffuse large B cell, 2 were MALT and 1 was follicular. None of their cases had concurrent mammary amyloidosis. ${ }^{22}$ In our study, MALT lymphoma was present in $35 \%$ of cases of breast amyloidosis, whereas only one case $(3 \%)$ had concurrent small lymphocytic lymphoma and none had diffuse large B-cell lymphoma or follicular lymphoma. Therefore, MALT lymphoma of the breast should be excluded in any patient with mammary amyloidosis. Conversely, Congo red stain is recommended on breast samples showing MALT lymphoma to rule out concurrent amyloidosis.

In summary, breast amyloidosis is of the AL type in most patients, and in contrast to generalized amyloidosis, it is usually of the kappa type. Almost half of the patients have systemic amyloidosis and over half have concurrent hematologic disorders in the breast. Therefore, further work up to rule out hematologic malignancy and/or systemic amyloidosis is recommended in patients with breast amyloidosis. Mass spectrometry-based proteomics is superior to immunohistochemistry and is a powerful tool to establish the type of breast amyloidosis.

\section{Disclosure/conflict of interest}

The authors declare no conflict of interest.

\section{References}

1 Merlini G, Seldin DC, Gertz MA. Amyloidosis: pathogenesis and new therapeutic options. J Clin Oncol 2011;29:1924-1933.

2 Murphy C, Wang S, Kestler D, et al. Leukocyte chemotactic factor 2 (LECT2)-associated renal amyloidosis. Amyloid 2011;18(Suppl 1):218-220.

3 Charlot M, Seldin DC, O'hara C, et al. Localized amyloidosis of the breast: a case series. Amyloid 2011; 18:72-75.

4 Röcken C, Kronsbein H, Sletten K, et al. Amyloidosis of the breast. Virchows Arch 2002;440:527-535.

5 Lew W, Seymour AE. Primary amyloid tumor of the breast. Case report and literature review. Acta Cytol 1985;29:7-11.

6 McMahon RF, Connolly CE. Amyloid breast tumor. Am J Surg Pathol 1987;11:488. 
7 McMahon RF, Waldron D, Given HF, et al. Localised amyloid tumour of breast-a case report. Ir J Med Sci 1984;153:323-324.

8 Silverman JF, Dabbs DJ, Norris HT, et al. Localized primary (AL) amyloid tumor of the breast. Cytologic, histologic, immunocytochemical and ultrastructural observations. Am J Surg Pathol 1986;10:539-545.

9 Fernandez BB, Hernandez FJ. Amyloid tumor of the breast. Arch Pathol 1973;95:102-105.

10 Toohey JM, Ismail K, Lonergan D, et al. Amyloidosis of the breast mimicking recurrence in a previously treated early breast cancer. Australas Radiol 2007;51: 594-596.

11 Sadeghee SA, Moore SW. Rheumatoid arthritis, bilateral amyloid tumors of the breast, and multiple cutaneous amyloid nodules. Am J Clin Pathol 1974;62:472-476.

12 Santini D, Pasquinelli G, Alberghini M, et al. Invasive breast carcinoma with granulomatous response and deposition of unusual amyloid. J Clin Pathol 1992;45: 885-888.

13 Tirzaman O, Wahner-Roedler DL, Malek RS, et al. Primary localized amyloidosis of the urinary bladder: a case series of 31 patients. Mayo Clin Proc 2000;75:1264-1268.

14 Sethi S, Gamez JD, Vrana JA, et al. Glomeruli of dense deposit disease contain components of the alternative and terminal complement pathway. Kidney Int 2009;75:952-960.

15 Rodriguez FJ, Gamez JD, Vrana JA, et al. Immunoglobulin derived depositions in the nervous system: novel mass spectrometry application for protein characterization in formalinfixed tissues. Lab Invest 2008;88: 1024-1037.

16 Vrana JA, Gamez JD, Madden BJ, et al. Classification of amyloidosis by laser microdissection and mass spectrometry-based proteomic analysis in clinical biopsy specimens. Blood 2009;114:4957-4959.

17 Kyle RA, Gertz MA. Primary systemic amyloidosis: clinical and laboratory features in 474 cases. Semin Hematol 1995;32:45-59.

18 O'Connor CR, Rubinow A, Cohen AS. Primary (AL) amyloidosis as a cause of breast masses. Am J Med 1984;77:981-986.

19 Lamovec J, Jancar J. Primary malignant lymphoma of the breast. Lymphoma of the mucosa-associated lymphoid tissue. Cancer 1987;60:3033-3041.

20 Gupta D, Shidham V, Zemba-Palko V, et al. Primary bilateral mucosa-associated lymphoid tissue lymphoma of the breast with atypical ductal hyperplasia and localized amyloidosis. A case report and review of the literature. Arch Pathol Lab Med 2000;124:1233-1236.

21 Yokoo H, Nakazato Y. Primary localized amyloid tumor of the breast with osseous metaplasia. Pathol Int 1998; 48:545-548.

22 Lin YC, Tsai $\mathrm{CH}, \mathrm{Wu}$ JS, et al. Clinicopathologic features and treatment outcome of non-Hodgkin lymphoma of the breast-a review of 42 primary and secondary cases in Taiwanese patients. Leuk Lymphoma 2009;50:918-924. 